16. The harmonization and optimization of diagnostic methods for a belt conveyor / Helebrant F. et. al. // Management Systems in Production Engineering. 2012. Issue 2 (6). P. 39-44.

17. Moni V., Klouda P., Skraban V. Comprehensive Check Measurement of Key Parameters on Model Belt Conveyor / Management Systems in Production Engineering. 2013. Issue 11 (3). P. 24-27.

18. To issue of ecological safety quantitative evaluation at EIA Statiuha G. O. et. al. // Eastern-European Journal of Enterprise Technologies. 2010. Vol. 6, Issue 6 (48). P. 44-46. URL: http://journals.uran.ua/eejet/article/view/3347/3147

19. Kozulia T. V., Emel'ianova D. I., Kozulia M. M. Complex ecological estimation of natural and manmade complexes which basis on MIPS- and risk analysis // Eastern-European Journal of Enterprise Technologies. 2014. Vol. 3, Issue 10 (69). P. 8-13. doi: http://doi.org/10.15587/1729-4061.2014.24624

20. Bugaieva L. M., Osmanov M. M., Statiuha G. O. Using system dynamics methods to study the sustainable development of regions of Ukraine. Eastern-European Journal of Enterprise Technologies. 2010. Vol. 2, Issue 10 (44). P. 22-25. URL: http:// journals.uran.ua/eejet/article/view/2772/2578
21. Antonets A. V., Pliatsuk D. L. Analysis of information-analytical systems development of environmentally dangerous situation modeling // Technology Audit and Production Reserves. 2015 Vol. 6, Issue 2 (26). P. 8-12. doi: http://doi.org/10.15587/23128372.2015 .56800

Simonenko Vladimir, Doctor of Technical Sciences, Professor Department of Open Cast Mining, National Technical University «Dnipro Polytechnic», Ukraine, e-mail: symonenko.vi@nmu.one, ORCID: http://orcid.org/0000-0002-9409-7813

Pavlychenko Artem, Doctor of Technical Sciences, Associate Professor, Head of Department, Department of Ecology and Technologies of Environmental Protection, National Technical University «Dnipro Polytechnic», Ukraine, e-mail: pavlychenkoa@nmu.org.ua, ORCID: http://orcid.org/0000-0003-4652-9180

Cherniaiev Oleksii, Researcher, Institute for the Design of Mining Enterprises, National Technical University «Dnipro Polytechnic», Ukraine, e-mail: chernyaev.aleksey82@ukr.net, ORCID: http:// orcid.org/0000-0001-8288-4011

\section{Shuryberko M., Gomelya M., Shabliy T., Chuprova K.}

\title{
DEVELOPMENT OF REAGENTS FOR PROTECTION OF EOUIPMENT OF WATER SUPPLY SYSTEMS FROM SCALE AND CORROSION
}

Об’єктом дослідження є екологічно безпечні водоциркуляційні теплообмінні системи в промисловості та комунальних господарствах. На діючих підприємствах в процесі модернізації систем водокористування часто переходять на використання інгібіторів корозії металів та накипоутворення. Після тривалого періоду експлуатацї даних систем заміни обладнання не проводиться. Одним з найбільш проблемних місць реконструкцї є наявність продуктів накипоутворення та корозії на внутрішній поверхні теплообмінного обладнання. Ці утворення знижують ефективність теплопереносу і нівелюють ефективність інгібіторів корозії та стабілізаторів накипоутворення.

В роботі проведено оцінку ефективності композицій, запропонованих в якості травильних розчинів для очищення поверхонь металу від осадовідкладень, а також в якості стабілізаторів накипоутворення. В ході дослідження використовувалися композицї, створені на основі неорганічних кислот в присутності уротропіну, уротропіну з тіокарбамідом.

Результати досліджень вказують, що найменшою корозійною агресивністю серед розглянутих варіантів характеризується композиція Р-29. Глибинний показник корозї 0,118907 мм/рік. Показник руйнування хімічноосадженого гіпсу складає не менше $90 \%$.

3 метою ефективного та тривалого використання теплообмінного обладнання доцільно застосовувати інгібітори корозії та накипоутворення. В роботі представлена нова композиція Р-33, яка в концентрації

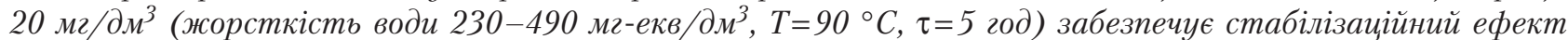
56,0-93,3 \%, а протинакипний ефект - 95,5-99,3 \%. 3 підвищенням концентрацї реагенту до 50 \% стабілізаційний та протинакипний ефекти сягають $100 \%$

Розроблені композицї для очищення поверхонь теплообмінного обладнання на основі доступних недорогих реагентів, які переважають аналоги за ефективністю, характеризуються низькою корозійною активністю та забезпечують видалення з поверхні металу малорозчинних хімічно стійких речовин (гіпсу). Композиція Р-33 переважає аналоги тим, що забезпечує стабілізацію щодо осадовідкладень у розчинах гіпсу в присутності карбонатів кальщію та магнію при високих температурах.

Ключові слова: стабілізатор накипоутворення, інгібітор корозї, водоціркуляційні системи, відновлення поверхонь металевого обладнання, корозійна агресивність водних середовищ.

\section{Introduction}

At existing enterprises, in the processes of modernization of water use systems, in particular, cooling systems, they often switch to the use of corrosion inhibitors for metals and scale formation. However, after a long period of operation of these systems, full replacement of pipelines and equipment is not performed. The internal surfaces 
of heat exchange equipment and pipelines are covered with scale and corrosion products [1], which significantly reduce the efficiency of heat transfer and almost completely eliminate the effectiveness of corrosion inhibitors and scale builders.

To ensure the proper effectiveness of the reagents, it is necessary either to increase their concentrations by tens to hundreds of times, or to pre-clean the internal surfaces of pipelines and heat exchangers from deposits. The first option is inexpedient both from ecological and economic points of view. In the case of a successful selection of a composition for cleaning the surfaces of deposits from scales, the result of the further use of inhibitors is economically viable and time consuming.

Therefore, research in the field of protection of metal structures against corrosion and scale is relevant. In particular, the creation of complex and inexpensive inhibitors of corrosion and scale of deposits, which are effective in a wide temperature range and universal for various types of metals and solutions of different chemical composition.

\section{The object of research and its technological audit}

The object of research is environmentally friendly waterexchange systems in the energy, industry and utilities.

In industry and energy, approximately $80 \%$ of water is used in water cooling systems. In the absence of pretreatment of water for cooling systems in order to maintain the salt balance in the system, 8 to $30 \%$ of water is discharged daily into the hydrosphere. At the same time, physical (thermal) and chemical (copper and zinc ions, washed out from copper and brass capacitors) pollution of reservoirs is observed.

On the other hand, an important issue is the protection of metal structures against corrosion in water and aqueous solutions. High corrosivity of environments leads to significant costs of materials, water and energy.

Therefore, the priority is creation of effective ways of water conditioning. This will allow moving to closed cooling systems, which, in turn, will ensure a reduction in fresh water intake for industrial facilities and a reduction in industrial wastewater [2].

One of the ways to solve this problem is to use metal corrosion inhibitors and scale formation stabilizers in water treatment processes. The main requirements for modern compositions are their high efficiency, complexity of action and non-toxicity [3]. That is, inhibitors that are used in circulating systems must protect metals from corrosion and simultaneously reduce scale deposits on the surface of heat exchange equipment.

\section{The aim and objectives of research}

The aim of research is determination of the effectiveness of compositions based on inorganic acids as corrosionresistant pickling solutions for the restoration of metal pipe surfaces, as well as compositions for permanent use in water conditioning processes.

To achieve this aim it is necessary to perform the following tasks:

1. To evaluate the corrosivity of the compositions of etching solutions for cleaning metal surfaces using the mass metric method and the method of polarization resistance.
2. To establish the dependence of the solubility of calcium sulfate in acidic environments, which differ in chemical composition and concentration.

3. To evaluate the effectiveness of the use of the proposed compositions as stabilizers of scale formation by determining the stabilization and anti-scale effects of aqueous solutions of different composition.

\section{Research of existing solutions of the problem}

As a result of long-term use of heat exchange equipment at industrial facilities, metal surfaces of pipelines, boilers, etc. are covered with a layer of corrosion products and carbonate-sulphate scale deposits $[4,5]$. The simplest and most affordable way to restore the surfaces of pipelines, heat exchangers, boilers is washing them with acidic solutions [6, 7].

However, the use of pure acids for flushing pipes has several disadvantages. The authors of $[8,9]$ emphasize the danger of using inorganic acids as etching solutions. In particular, the use of sulfuric acid [8] leads to the formation of insoluble calcium sulfate, and hydrochloric acid [9] due to the presence of chlorides - to an increase in the aggressiveness of the environment.

An alternative is the use of organic acids. It is known that sulfamic acid (10\% solution) is an effective reagent for cleaning pipes from corrosion and scale products. However, this solution is corrosive to steel 20. The average polarization resistance $\left(R p_{a v}\right)$ is 70 Ohms [10].

At the present stage, phosphoric acids are the most effective stabilizers of scale formation [2, 11]. And their zinc salts are the most effective inhibitors of metal corrosion [3, 11]. However, the issue remains the use of these acids as etching solutions.

Thus, the results of literary analysis allow to conclude that, despite the long period of use of water circulation systems in industry [1], the issue of recovering metal equipment remains not fully resolved. In particular, there is a lack of effective and at the same time corrosive pickling solutions for cleaning metal surfaces from scales.

\section{Methods of research}

In preliminary studies [10], it was shown that the composition of thiocarbamide and urotropin exhibits a synergistic effect in protecting the metal surface from corrosion. Therefore, the compositions of etching solutions based on hydrochloric, sulfuric, phosphoric acids in the presence of urotropin or urotropin with thiocarbamide were used in the work.

Evaluation of corrosion of the proposed compositions was carried out in two ways: by the method of polarization resistance and by the mass metric method.

The polarization resistance was determined using the polarization resistance indicator P5126 (Ukraine) and a twoelectrode sensor from a UK-2 corrosion-indicating device (Ukraine) with electrodes made of steel 20, previously processed and weighted. The sensor was installed in a $150 \mathrm{~cm}^{3}$ container, and at certain intervals for two hours, the polarization resistance $R p(\mathrm{Ohm})$ was measured using the indicator P5126. The magnitude of the polarization resistance is inversely proportional to the corrosion rate of the metal. 
Mass metric determination of the corrosion rate was determined by the difference in mass of the sample, corroded, in grams before and after corrosion. The duration of the experiments was 18-23 hours.

The experiments were carried out in stationary environments at a temperature of $15-20{ }^{\circ} \mathrm{C}$ in free contact of water with air.

Mass metric indicator of corrosion, $\mathrm{g} /\left(\mathrm{m}^{2} \mathrm{~h}\right)$ :

$$
K_{m}=\frac{\left(m_{1}-m_{2}\right)}{S \cdot \tau},
$$

where $m_{1}$ - the initial mass of the sample, g; $m_{2}$ - the mass of the sample after the test, g; $S$ - the sample area, $\mathrm{m}^{2}$; $\tau$ - the test duration, h.

Deep corrosion rate, $\mathrm{mm} / \mathrm{year}$ :

$$
R=\frac{K_{m} \cdot 8.76}{d_{m e}},
$$

where $K_{m}$ - the mass metric index of corrosion, $\mathrm{g} /\left(\mathrm{m}^{2} \cdot \mathrm{h}\right)$; $d_{m e}$ - metal density, $\mathrm{g} / \mathrm{cm}^{3} ; 8.76$ - the coefficient calculated by the number of hours per year (8760) divided by 1000 .

Evaluation of the effectiveness of the developed compositions as stabilizers of scale formation was determined by changing the hardness of water when it is heated. Determination of the stabilization effect (SE) was carried out in closed containers at a temperature of $90-100{ }^{\circ} \mathrm{C}$ for 5 hours. The anti-scale effect was determined at a temperature of $40-60{ }^{\circ} \mathrm{C}$ in open glasses with water evaporation $37.5 \%$ (evaporation coefficient 1.6).

Stabilization effect, \%:

$$
S E=\left(1-\frac{H_{\text {in }}-H_{r}}{H_{\text {in }}-H_{0}}\right) \cdot 100,
$$

where $H_{i n}, H_{r}$ - initial and residual hardness of water, mg-eq $/ \mathrm{dm}^{3}$, respectively; $H_{0}$ - residual hardness of water without the use of a stabilizer, mg-eq $/ \mathrm{dm}^{3}$.

Anti-scale effect, \%:

$$
A E=\frac{H_{r}}{H_{\text {in }}} \cdot 100 .
$$

The residual calcium concentration in the samples was determined using trilonometry with eriochrome black $T$ indicator.

\section{Research results}

A fairly common alloy that has been used in the machinebuilding industry for a long period is steel 20. In particular, its mechanical properties determine the widespread use of this brand in boiler-making, the manufacture of pipes and heating elements for various purposes. Therefore, all studies in the work carried out with steel 20 .

As can be seen from the above results (Fig. 1), in static conditions the polarization resistance of tap water in the Kyiv (Ukraine) is insignificant and amounts to 305-316 ohms. Solutions of hydrochloric, sulfuric, phosphoric acids, in concentrations of $10 \%$, cause significant corrosion of steel 20. The polarization resistance of these solutions is respectively 5.3; 8.4 and $15.1 \mathrm{ohms}$. Adsorbing on the surface of the metal, these anions form compounds that have good solubility. This leads to an increase in the corrosion rate of steel. The most aggressive are chloride anions, which are able to easily penetrate protective surface films of the metal.

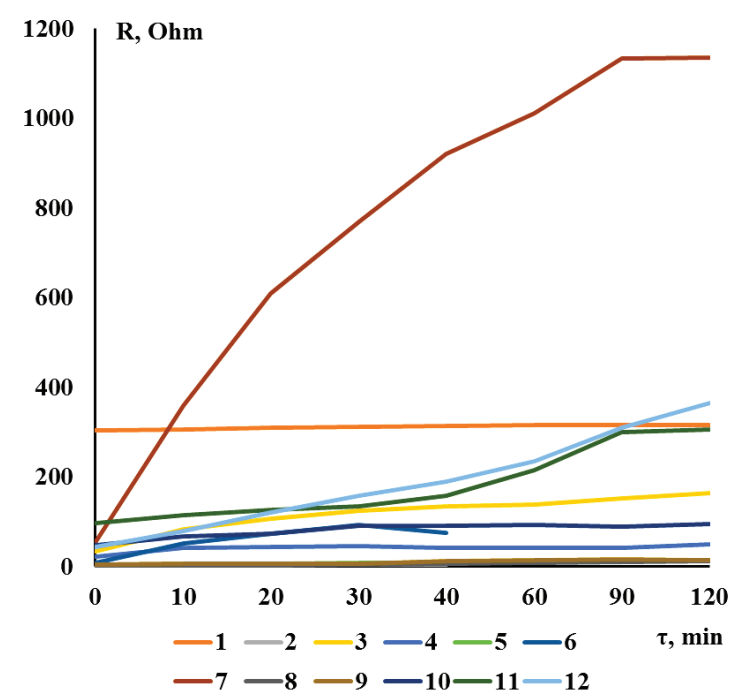

Fig. 1. Dependence of the polarization resistance on the composition of the initial solution under static conditions: 1 - tap water (Kyiv, Ukraine), 2 - HCl (100 g/ $\left.\mathrm{dm}^{3}\right)$;

3 - HCl:uratrapin (100:5); 4 - HCl:urotropin:thiocarbamide (100:5:1) $5-\mathrm{H}_{2} \mathrm{SO}_{4}\left(100 \mathrm{~g} / \mathrm{dm}^{3}\right) ; 6-\mathrm{H}_{2} \mathrm{SO}_{4}$ :uratropin (100:5);

$7-\mathrm{H}_{2} \mathrm{SO}_{4}$ :urotropin:thiocarbamide (100:5:1); $8-\mathrm{H}_{3} \mathrm{PO}_{4}\left(50 \mathrm{~g} / \mathrm{dm}^{3}\right)$;

$9-\mathrm{H}_{3} \mathrm{PO}_{4}\left(100 \mathrm{~g} / \mathrm{dm}^{3}\right) ; 10-\mathrm{H}_{3} \mathrm{PO}_{4}$ :uratropin (50:5);

$11-\mathrm{H}_{3} \mathrm{PO}_{4}$ :urotropin: thiocarbamide (50:5:1);

$12-\mathrm{H}_{3} \mathrm{PO}_{4}$ :urotropin:thiocarbamide (100:5:1)

The presence of urotropin in a concentration of $5 \mathrm{~g} / \mathrm{dm}^{3}$ in the solution leads to an increase in the polarization resistance, that is, to an increase in the protective effect. The maximum protective effect after 2 hours is observed:

- for a mixture of hydrochloric acid and urotropin in

a ratio of 100:5, and the polarization resistance increases to 164.5 ohms;

- for sulfuric acid with urotropin (100:5), this indicator rises to 75.3 ohms;

- for a mixture of phosphoric acid and urotropin (50:5), it reaches 94.5 ohms.

However, the corrosion rate in these environments is large compared to tap water.

The result of adding thiocarbamide is not straightforward. So, its use in a mixture with hydrochloric acid and urotropin (100:5:1) has a negative effect - the polarization resistance is reduced to $49.8 \mathrm{ohms}$. In the presence of phosphoric acid under the same conditions, this indicator reaches the values of tap water and is 365 ohms. An impressive effect is observed when used in a mixture of sulfuric acid: the polarization resistance increases to $1136 \mathrm{ohms}$.

The reliability of the obtained results is confirmed by experiments carried out by the mass metric method (Table 1 ).

As can be seen from results in the Table 1, all compositions have a greater corrosive aggressiveness than tap water, the deep corrosion rate of which is $0.015618 \mathrm{~mm} /$ year. The least corrosive aggressiveness among the options considered is characterized by the P-29 composition. The metric corrosion rate of this composition is $0.106881 \mathrm{~g} /\left(\mathrm{m}^{2} \mathrm{~h}\right)$, the deep corrosion rate, respectively, is $0.118907 \mathrm{~mm} /$ year. A P-29 composition, created on the basis of orthophosphoric 
acid, is used as a reagent for removing scale formation products - calcium carbonates and sulphates. Its rate of destruction of chemically scaled gypsum is at least $90 \%$. Therefore, let's assume that the P-29 composition is an effective corrosion-insensitive reagent for cleaning the equipment of water supply systems from salt decomposition and corrosion.

Table 1

Corrosion of steel in solutions of acids and acidic compositions

\begin{tabular}{|c|c|c|c|c|}
\hline \multirow[b]{2}{*}{ No. } & \multirow[b]{2}{*}{ Solution } & \multirow[b]{2}{*}{$\begin{array}{l}\text { Concen- } \\
\text { tration, } \\
\mathrm{g} / \mathrm{dm}^{3}\end{array}$} & \multicolumn{2}{|c|}{ Corrosion rate } \\
\hline & & & $\begin{array}{c}\text { Mass metric, } \\
\mathrm{g} /\left(\mathrm{m}^{2} \cdot \mathrm{h}\right)\end{array}$ & $\begin{array}{l}\text { Deep corrosion rate, } \\
\mathrm{mm} / \mathrm{year} \text { (mass metric } \\
\mathrm{method} / \mathrm{method} \text { of po- } \\
\text { larization resistance) }\end{array}$ \\
\hline 1 & Tap water & - & 0.014012 & 0.015618 \\
\hline 2 & $\mathrm{HCl}$ & 50 & 2.903103 & 3.229766 \\
\hline 3 & $\mathrm{HCl}$ & 100 & 5.192697 & $5.776991 / 10.63869$ \\
\hline 4 & $\begin{array}{c}\mathrm{HCl} \\
\text { uratropin }\end{array}$ & $\begin{array}{c}50 \\
5\end{array}$ & 0.203566 & 0.226472 \\
\hline 5 & $\begin{array}{c}\mathrm{HCl} \\
\text { uratropin }\end{array}$ & $\begin{array}{l}50 \\
10\end{array}$ & 0.247372 & 0.275206 \\
\hline 6 & $\begin{array}{c}\text { HCl } \\
\text { uratropin }\end{array}$ & $\begin{array}{c}100 \\
5\end{array}$ & 0.324675 & $0.361209 / 0.392655$ \\
\hline 7 & $\begin{array}{c}\text { HCl } \\
\text { urotropin }\end{array}$ & $\begin{array}{c}100 \\
10\end{array}$ & 0.373634 & 0.415676 \\
\hline 8 & $\mathrm{H}_{3} \mathrm{PO}_{4}$ & 50 & 2.591353 & 2.882938/2.734004 \\
\hline 9 & $\mathrm{H}_{3} \mathrm{PO}_{4}$ & 100 & 3.865855 & 4.300849/2.898746 \\
\hline 10 & $\begin{array}{c}\mathrm{H}_{3} \mathrm{PO}_{4} \\
\text { ammonia }\end{array}$ & $\begin{array}{c}100 \\
5\end{array}$ & 0.302843 & 0.336919 \\
\hline 11 & $\begin{array}{c}\mathrm{H}_{3} \mathrm{PO}_{4} \\
\text { ammonia } \\
\text { thiocarbamide }\end{array}$ & $\begin{array}{c}100 \\
5 \\
1\end{array}$ & 0.131168 & 0.145927 \\
\hline 12 & $\begin{array}{c}\mathrm{H}_{3} \mathrm{PO}_{4} \\
\text { ammonia } \\
\text { thiocarbamide }\end{array}$ & $\begin{array}{l}50 \\
5 \\
1\end{array}$ & 0.183512 & 0.204161 \\
\hline 13 & P-29 & $(\mathrm{pH}=1.66)$ & 0.106881 & 0.118907 \\
\hline
\end{tabular}

In many enterprises, the problem of scale formation on the heating surfaces of heat exchange equipment is acute. Together with the previous stabilization treatment of water for water systems, a painful issue remains the removal of scale from the surfaces of pipelines and equipment. Scale of calcium sulfate have particular concern, the solubility of which in acids is much less compared with calcium carbonate, as shown in the example of orthophosphoric acid (Table 2).

Table 2

The solubility of carbonate and calcium sulfate in phosphoric acid of various concentrations

\begin{tabular}{|c|c|c|}
\hline \multirow{2}{*}{$\mathrm{H}_{3} \mathrm{PO}_{4}$ concentration, $\mathrm{g} / \mathrm{dm}^{3}$} & \multicolumn{2}{|c|}{ Solubility, $\mathrm{g} / \mathrm{dm}^{3}$} \\
\cline { 2 - 3 } & $\mathrm{CaCO}_{3}$ & $\mathrm{CaSO}_{4}$ \\
\hline 10 & $10.3-10.9$ & $5.9-6.4$ \\
\hline 20 & $20.4-20.8$ & $6.5-6.9$ \\
\hline 30 & $31.4-32$ & $7.2-7.7$ \\
\hline 50 & $43.1-43.6$ & $10.4-10.9$ \\
\hline 100 & $49.8-50.3$ & $11.4-11.9$ \\
\hline
\end{tabular}

So, in the range of concentrations of orthophosphoric acid $10-100 \mathrm{~g} / \mathrm{dm}^{3}$, the solubility of calcium carbonate is 4.5 times greater than the solubility of calcium sulfate.

It should be noted that orthophosphoric acid has a significantly lower ability to dissolve calcium sulfate compared with other inorganic and organic acids and is $11.4-11.9 \mathrm{~g} / \mathrm{dm}^{3}$ for a $10 \%$ solution (Table 3 ).

Table 3

Calcium sulphate solubility in various environments

\begin{tabular}{|c|c|c|}
\hline Reagent & Concentration, $\mathrm{g} / \mathrm{dm}^{3}$ & $\mathrm{CaSO}_{4}$ solubility, $\mathrm{g} / \mathrm{dm}^{3}$ \\
\hline Tap water & - & 1.76 \\
\hline \multirow{3}{*}{$\mathrm{H}_{3} \mathrm{PO}_{4}$} & 30 & $7.2-7.7$ \\
\hline & 50 & $10.4-10.9$ \\
\hline & 100 & $11.4-11.9$ \\
\hline \multirow{3}{*}{$\mathrm{HCl}$} & 30 & $24.5-24.9$ \\
\hline & 50 & $30.3-30.8$ \\
\hline & 100 & $36.2-36.7$ \\
\hline \multirow{3}{*}{$\begin{array}{c}\text { Hydraxyethylene } \\
\text { diphosphonic acid } \\
\text { (HEDP) }\end{array}$} & 30 & 12.1-12.6 \\
\hline & 50 & $13.4-13.9$ \\
\hline & 100 & 18.0-18.5 \\
\hline \multirow{3}{*}{$\begin{array}{l}\text { Nitrile trimethyl- } \\
\text { phosphonic acid } \\
\text { (NTMP) }\end{array}$} & 30 & $9.3-9.8$ \\
\hline & 50 & $11.7-12.2$ \\
\hline & 100 & $17.7-18.2$ \\
\hline \multirow{3}{*}{ sulfamic acid } & 30 & $7.5-8.0$ \\
\hline & 50 & 10.2-10.7 \\
\hline & 100 & 17.6-18.1 \\
\hline $\begin{array}{l}\mathrm{H}_{3} \mathrm{PO}_{4} \\
\mathrm{NH}_{4} \mathrm{OH} \\
\mathrm{NTMP}^{2}\end{array}$ & $\begin{array}{l}50 \\
5 \\
5\end{array}$ & $7.0-7.5$ \\
\hline
\end{tabular}

The highest solubility for calcium sulfate has hydrochloric acid. So, for hydrochloric acid with a concentration of $30 \mathrm{~g} / \mathrm{dm}^{3}$, this indicator is $24.5-24.9 \mathrm{~g} / \mathrm{dm}^{3}$. In a more concentrated solution $(10 \%)$, the solubility increases to $36.2-36.7 \mathrm{~g} / \mathrm{dm}^{3}$.

Calcium sulfate in phosphonic acids is $2.0-2.5$ times less than in hydrochloric acid. For their solutions in concentrations of $10 \%$, this indicator is about $18 \mathrm{~g} / \mathrm{dm}^{3}$. However, their use for laundering equipment is advisable, since these compounds are effective stabilizers of scale formation and metal corrosion inhibitors [11].

Creating compositions based on the considered acids, for example, $\mathrm{H}_{3} \mathrm{PO}_{4}+\mathrm{NH}_{4} \mathrm{OH}+\mathrm{NTMP}$, does not always lead to an increase in the effect of dissolution, as is observed in the case of P-29 composition. Although, as can be seen from Fig. 2, there is a definite correlation between the intensity (time) of dissolution and the composition: calcium sulfate ratio. So, with an increase in the volume of the pickling solution under conditions of the same mass of calcium sulfate, a reduction in the time of dissolution of the latter is observed.

The key to effective and long-term use of new and reconditioned heat exchange equipment is the constant use of corrosion and scale inhibitors. The aim of modern developments in the field of water temperature is the creation of reagents with high efficiency and complexity of action both as corrosion inhibitors of metals and scale stabilizers. 


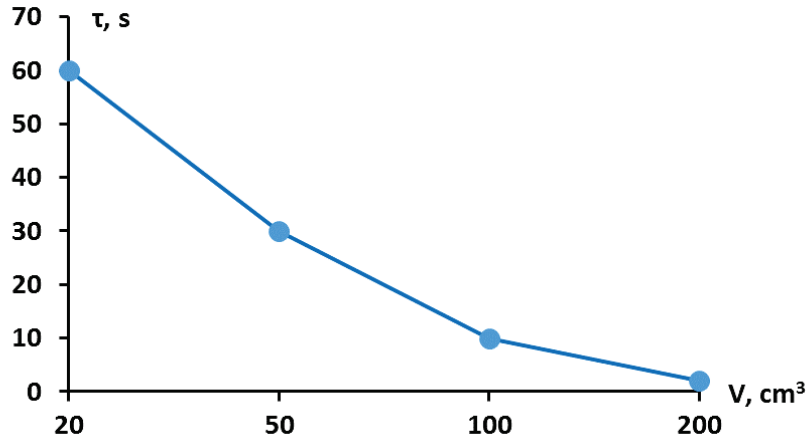

Fig. 2. The dependence of the intensity of dissolution of calcium sulfate from the volume of the pickling solution

Among the known inhibitors, phosphon and nitrile phosphonic acids are also effective. HEDP and NTMP are effective scale stabilizers [11]. Their stabilization effects for tap water at $90{ }^{\circ} \mathrm{C}$ are $69.9 \%$ and $86.7 \%$, respectively. But they are expensive and their use for large cooling systems is uneconomical.

Based on these acids, a new composition P-33, a reagent to prevent scale, was developed. This mixture showed excellent results under the same harsh conditions $\left(T=90^{\circ} \mathrm{C}\right.$, $\tau=5 \mathrm{~h}$ ), but in more severe environments (Table 4).

Table 4

Dependence of stabilization and anti-scale effects on the concentration of reagent R-33 and the composition of the initial solution

\begin{tabular}{|c|c|c|c|c|}
\hline \multirow{2}{*}{$\begin{array}{l}\text { P-33 con- } \\
\text { centration, } \\
\mathrm{mg} / \mathrm{dm}^{3}\end{array}$} & \multicolumn{2}{|c|}{ Hardness of water, $\mathrm{mg}-\mathrm{eq} / \mathrm{dm}^{3}$} & \multirow{2}{*}{$\begin{array}{l}\text { Stabilization } \\
\text { effect, \% }\end{array}$} & \multirow{2}{*}{$\begin{array}{l}\text { Anti-scale } \\
\text { effect, \% }\end{array}$} \\
\hline & $H_{\text {in }}$ & $H_{\Gamma}$ & & \\
\hline \multicolumn{5}{|c|}{ Distilled water, $73 \mathrm{~g} / \mathrm{dm}^{3} \mathrm{NaCl}, 10 \mathrm{~g} / \mathrm{dm}^{3} \mathrm{MgSO}_{4}, 10 \mathrm{~g} / \mathrm{dm}^{3} \mathrm{CaCl}_{2}{ }^{*}, * *$} \\
\hline 0 & \multirow{4}{*}{230} & 212 & - & - \\
\hline 20 & & 228 & 88.9 & 99.1 \\
\hline 50 & & 230 & 100 & 100 \\
\hline 100 & & 230 & 100 & 100 \\
\hline \multicolumn{5}{|c|}{ Tap water, $73 \mathrm{~g} / \mathrm{dm}^{3} \mathrm{NaCl}, 10 \mathrm{~g} / \mathrm{dm}^{3} \mathrm{MgSO}_{4}, 10 \mathrm{~g} / \mathrm{dm}^{3} \mathrm{CaCl}_{2}$} \\
\hline 0 & \multirow{4}{*}{284} & 254 & - & - \\
\hline 20 & & 282 & 93.3 & 99.3 \\
\hline 50 & & 284 & 100 & 100 \\
\hline 100 & & 284 & 100 & 100 \\
\hline \multicolumn{5}{|c|}{ Tap water, $73 \mathrm{~g} / \mathrm{dm}^{3} \mathrm{NaCl}, 20 \mathrm{~g} / \mathrm{dm}^{3} \mathrm{MgSO}_{4}, \mathrm{~g} / \mathrm{dm}^{3} \mathrm{CaCl}_{2}$} \\
\hline 0 & \multirow{4}{*}{490} & 440 & - & - \\
\hline 20 & & 468 & 56 & 95.5 \\
\hline 50 & & 490 & 100 & 100 \\
\hline 100 & & 490 & 100 & 100 \\
\hline \multicolumn{5}{|c|}{ Tap water, $100 \mathrm{~g} / \mathrm{dm}^{3} \mathrm{NaCl}$} \\
\hline 0 & \multirow{4}{*}{5,5} & 5.1 & - & - \\
\hline 10 & & 5.5 & 100 & 100 \\
\hline 20 & & 5.5 & 100 & 100 \\
\hline 50 & & 5.5 & 100 & 100 \\
\hline
\end{tabular}

Note: * - mass metric indicator of corrosion, P-33 mg/dm ${ }^{3}-\mathrm{g} /\left(\mathrm{m}^{2} \mathrm{~h}\right)$ : 0 - 0.148423; 2 - 0.097403; 5 - 0.104259; 10 - 0.097604; ${ }^{* *}$ - deep corrosion indicator, P-33 mg/dm 3 - mm/year: 0 - 0.165439; 2 - 0, "108570; $5-0.116212 ; 10-0.108794$
Even at such high output water hardness (230$490 \mathrm{mEq} / \mathrm{dm}^{3}$ ), P-33 reagent at a concentration of $20 \mathrm{mg} / \mathrm{dm}^{3}$ provides a stabilization effect at the level of 56.0-93.3 \%, and an anti-scale effect - 95.5-99 $3 \%$. With an increase in the concentration of the reagent up to $50 \%$, the stabilization and anti-scale effects reach $100 \%$.

\section{SWOT analysis of research results}

Strengths. The developed compositions for cleaning pipelines, surfaces of heat exchange equipment based on affordable low-cost reagents, which are dominated by analogues in efficiency, are characterized by low corrosivity and ensure the removal from the metal surface of even poorly soluble chemically resistant substances, including gypsum deposits. In neutral environments, the main components of P-29 reagent are scale inhibitors and corrosion inhibitors. The created P-33 composition surpasses the analogs in that it provides scale stabilization in highly concentrated gypsum solutions in the presence of calcium and magnesium carbonates at high temperatures. The integrated use of reagents for cleaning pipelines and the use of scale formation stabilizers will increase the efficiency and reliability of equipment operation in heat supply systems and in water cooling systems for pipeline protection in the gas and oil producing industry.

Weaknesses. The use of acid solutions for cleaning pipelines involves the observance of a number of measures for the safe conduct of technological operations, the use of special acid-resistant containers, acid-resistant dosing pumps and other equipment. Spent solutions must be neutralized and disposed of according to existing regulations. When using scale inhibitors, it is necessary to use high-precision dosing devices.

Opportunities. In the case of effective cleaning of metal surfaces of heat exchange equipment with the subsequent use of corrosion inhibitors and scale deposits in water systems, it is possible to increase the service life of heat exchange units by $5-10$ times. In addition, in cooling systems it is possible to switch to drainless mode and refuse to discharge circulating water to purge of the system.

Threats. In the case of acid cleaning from deposits of surfaces, there is a threat of their insufficiently effective washing of residues of acidic reagents, which can affect equipment corrosion processes when the reaction of the medium in operating systems is acidic. Under normal operating conditions of systems, this threat is unrealistic. With the use of scale stabilizers, the level of water hardness in water systems may increase several times. This helps to reduce the corrosivity of water, but in the case of inadequate control of the dosing of the scale inhibitor, the scale deposition on the heat exchange surfaces is possible. It is also possible the threat of exceeding the permissible concentrations of reagents in the discharge of water during the purge of the system.

\section{Conclusions}

1. As a result of the experimental and computational studies, the corrosivity of the compositions of etching solutions for the cleaning of metal surfaces by the mass metric method and the method of polarization resistance is evaluated. It is shown that all compositions created on the basis of hydrochloric, sulfuric, phosphoric acids in the 
presence of urotropin or urotropin with thiocarbamide, have a greater corrosiveness than tap water. The least corrosive aggressiveness among the options considered is characterized by the P-29 composition. The mass metric corrosion rate of this composition is $0.106881 \mathrm{~g} /\left(\mathrm{m}^{2} \mathrm{~h}\right)$, the deep corrosion rate, respectively, is $0.118907 \mathrm{~mm} /$ year. A mixture of P-29, created on the basis of orthophosphoric acid, is used as a reagent for removing scale formation products - calcium carbonates and sulphates. Its rate of destruction of chemically shipped gypsum is at least $90 \%$. Therefore, it is possible to assume that the P-29 composition is an effective corrosion-insensitive reagent for cleaning the equipment of water supply systems from salt decomposition and corrosion.

2. The dependences of the solubility of gypsum in acidic environments, which are characterized by different chemical compositions and concentrations, are established. It is proved that the solubility of calcium carbonate and calcium sulfate differ significantly. At initial concentrations of orthophosphoric acid $10-100 \mathrm{~g} / \mathrm{dm}^{3}$, the solubility of calcium carbonate is 4.5 times greater than the solubility of calcium sulfate. If to compare the efficiency of dissolution of gypsum with various acids, then the highest solubility for calcium sulfate among the considered acids is hydrochloric acid. For hydrochloric acid with a concentration of $30 \mathrm{~g} / \mathrm{dm}^{3}$, this indicator is $24.5-24.9 \mathrm{~g} / \mathrm{dm}^{3}$. In a more concentrated solution (10\%), the solubility increases to $36.2-36.7 \mathrm{~g} / \mathrm{dm}^{3}$. Despite the lower solubility of calcium sulfate in phosphonic acids (2.0-2.5 times) compared with hydrochloric acid, their use for laundering equipment is advisable, since these compounds are effective scale stabilizers and inhibitors of metal corrosion. There is a definite correlation between the intensity (time) of dissolution and the composition: calcium sulfate ratio: with an increase in the volume of the pickling solution under conditions of the same mass of calcium sulfate, a decrease in the dissolution time of the latter is observed.

3. An evaluation is made of the effectiveness of using the developed P-33 composition as scale-forming stabilizers. This mixture shows excellent results in harsh conditions (water hardness $230-490 \mathrm{mg}-\mathrm{eq} / \mathrm{dm}^{3}, T=90{ }^{\circ} \mathrm{C}, \tau=5 \mathrm{~h}$ ). P-33 reagent at a concentration of $20 \mathrm{mg} / \mathrm{dm}^{3}$ provides a stabilization effect at the level of $56.0-93.3 \%$, and an anti-scale effect - 95.5-99.3\%. With an increase in the concentration of the reagent up to $50 \%$, the stabilization and anti-scale effects reach $100 \%$.

\section{References}

1. An overview of problems and solutions for components subjected to fireside of boilers / Singh A. et. al. // International Journal of Industrial Chemistry. 2017. Vol. 9, Issue 1. P. 1-15. doi: http://doi.org/10.1007/s40090-017-0133-0

2. Vitkovskyi V. S., Hlamazdin P. M., Haba K. O. Perspektyvy rozvytku novykh metodiv pidhotovky vody dlia system tsentralizovanoho teplopostachannia // Problemy vodopostachannia, vodovidvedennia ta hidravliky. 2016. Issue 27. P. 55-62.
3. New corrosion inhibition approach under high corrosive condition in cooling water systems / Kuribara T. et. al. // NACE International Corrosion Conference Series: Collaborate. Educate. Innovate. Mitigate. Dallas, 2015. 12 p.

4. Paher S. M., Herasymenko Yu. S. Modyfikatsiia karbonatnonakypnykh osadiv dlia zakhystu vid korozii teploobminnoi poverkhni // Visnyk Skhidnoukrainskoho natsionalnoho universytetu imeni Volodymyra Dalia. 2013. Issue 13. P. 54-65.

5. Corrosion failure analysis and anticorrosion measures for a tube bundle in a packing-type evaporative air cooler / Guo E. et. al. // Harbin Gogcheng Daxue Xuebao/Journal of Harbin Engineering University. 2016. Vol. 37, Issue 5. P. 743-746. doi: http://doi.org/10.11990/jheu.201507034

6. Sharma P., Roy H. Mill Scale Corrosion and Prevention in Carbon Steel Heat Exchanger // High Temperature Materials and Processes. 2015. Vol. 34, Issue 6. P. 571-576. doi: http:// doi.org/10.1515/htmp-2014-0115

7. Corrosion inhibition of N80 steel simulated in an oil field acidification environment / Du J. et. al. // International Journal of Electrochemical Science. 2018. Vol. 13, Issue 6 . P. 5810-5823. doi: http://doi.org/10.20964/2018.06.69

8. Deyab M. A. Corrosion inhibition of heat exchanger tubing material (titanium) in MSF desalination plants in acid cleaning solution using aromatic nitro compounds // Desalination. 2018. Vol. 439. P. 73-79. doi: http://doi.org/10.1016/ j.desal.2018.04.005

9. Synthesis, surface properties and inhibition behavior of novel cationic gemini surfactant for corrosion of carbon steel tubes in acidic solution / Hegazy M. A. et. al. // Journal of Molecular Liquids. 2015. Vol. 211. P. 126-134. doi: http://doi.org/ 10.1016/j.molliq.2015.06.051

10. Nosachova Yu. V. Stvorennia novykh zasobiv i tekhnolohii dlia zabezpechennia resursozberezhennia u promyslovomu vodospozhyvanni: PhD thesis. Kyiv: Natsionalnyi tekhnichnyi universytet Ukrainy «Kyivskyi politekhnichnyi instytut», 2006. 166 p.

11. New inhibitors of corrosion and depositions of sediments for water circulation systems / Gomelya N. D. et. al. // Journal of Water Chemistry and Technology. 2017. Vol. 39, Issue 2. P. 92-96. doi: http://doi.org/10.3103/s1063455x17020060

Shuryberko Mariia, Postgraduate Student, Department of Ecology and Plant Polymers Technology, National Technical University of Ukraine «Igor Sikorsky Kyiv Polytechnic Institute», Ukraine, e-mail: mashashuryberko@gmail.com,ORCID: http://orcid.org/00000001-5283-2069

Gomelya Mykola, Doctor of Technical Sciences, Professor, Head of the Department of Ecology and Plant Polymers Technology, National Technical University of Ukraine «Igor Sikorsky Kyiv Polytechnic Institute»,Ukraine, e-mail:m.gomelya@kpi.ua, ORCID: http://orcid.org/ 0000-0003-1165-7545

Shabliy Tetyana, Doctor of Technical Sciences, Professor, Department of Ecology and Plant Polymers Technology, National Technical University of Ukraine «Igor Sikorsky Kyiv Polytechnic Institute», Ukraine, e-mail: dsts1@ukr.net, ORCID: http://orcid.org/00000002-6710-9874

Chuprova Kristina, Department of Ecology and Plant Polymers Technology, National Technical University of Ukraine «Igor Sikorsky Kyiv Polytechnic Institute», Ukraine, e-mail: istiupro@gmail.com, ORCID: http://orcid.org/0000-0002-4713-3949 